\title{
A sneak preview
}

\author{
A. W. G. J. Oomen
}

Accepted: 26 July 2021 / Published online: 9 September 2021 (C) The Author(s) 2021

A 67-year-old female was seen at the outpatient clinic because of recurrent palpitations. She had no relevant past medical history. Physical examination and echocardiography did not reveal any abnormalities. An electrocardiogram (ECG) was recorded (Fig. 1).

How do you explain the rhythm in Fig. 1, and what arrhythmia is likely to be the cause of her palpitations?

\section{Answer}

You will find the answer elsewhere in this issue.

Conflict of interest A.W.G.J. Oomen declares that he/she has no competing interests.

Open Access This article is licensed under a Creative Commons Attribution 4.0 International License, which permits use, sharing, adaptation, distribution and reproduction in any medium or format, as long as you give appropriate credit to the original author(s) and the source, provide a link to the Creative Commons licence, and indicate if changes were made. The images or other third party material in this article are included in the article's Creative Commons licence, unless indicated otherwise in a credit line to the material. If material is not included in the article's Creative Commons licence and your intended use is not permitted by statutory regulation or exceeds the permitted use, you will need to obtain permission directly from the copyright holder. To view a copy of this licence, visit http://creativecommons.org/licenses/by/4.0/.

Fig. 1 Electrocardiogram at presentation

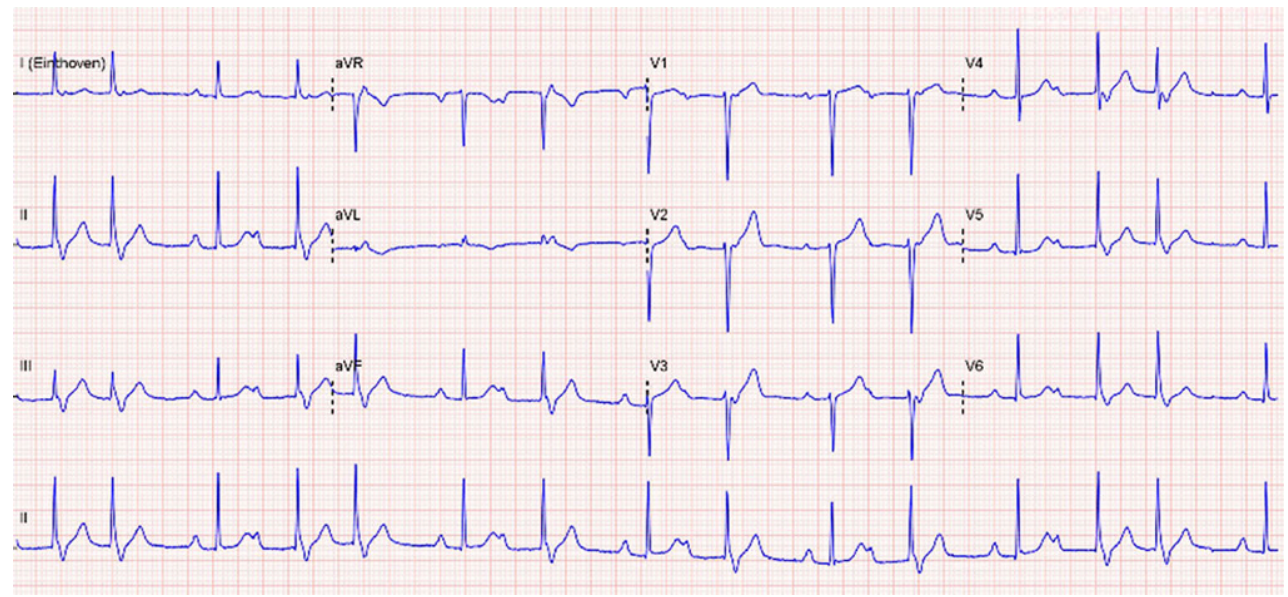

A. W. G. J. Oomen ( $ه)$

Department of Cardiology, Diakonessenhuis, Utrecht, The

Netherlands

aoomen@diakhuis.nl 